\title{
Konsepsi Perlindungan Hukum Bagi Anak sebagai Korban Kejahatan Siber Melalui Pendekatan Penal dan Non Penal ${ }^{*}$
}

\author{
Hardianto Djanggih** \\ Bidang Hukum Pidana, Fakultas Hukum Universitas Tompotika Luwuk Banggai \\ Jalan Dewi Sartika No. 67 Luwuk-Banggai, Sulawesi Tengah, 94715
}

\begin{abstract}
This study aims to examine the form of legal protection for children as victims of cyber crime through penal and non penal approach. Cyber crime that causes children as victims every year increases. The research is in studying using normative legal research method, by searching various sources of primary and secondary legal material described descriptively. The results showed that to cope with cyber crime that resulted in the child as a victim need to be protected in the form of penal and non penal policies. Penal policies by criminalizing various forms of crime are criminalized by offering the concept of criminal indemnification and special criminal sanctions. The non-penalty policy offered is restricting internet access to children. Keywords: legal protection, child, victim, cyber crime.
\end{abstract}

\section{Intisari}

Penelitian ini bertujuan untuk mengkaji bentuk perlindungan hukum bagi anak sebagai korban kejahatan siber melalui pendekatan penal dan non penal. Kejahatan siber yang mengakibatkan anak sebagai korban setiap tahun meningkat. Adapun penelitian ini dalam mengkajinya menggunakan metode penelitian hukum normatif dengan melakukan penelusuran berbagai sumber bahan hukum primer dan sekunder yang diuraikan secara deskriptif. Hasil penelitian menunjukkan bahwa untuk menanggulangi kejahatan siber yang mengakibatkan anak sebagai korban perlu dilakukan perlindungan dalam bentuk kebijakan penal dan kebijakan non penal. Kebijakan penal dengan mengkriminalisasi berbagai bentuk kejahatan menjadi tindak pidana dengan menawarkan konsep pidana ganti kerugian dan pidana minimal khusus. Kebijakan non penal yang ditawarkan yaitu pembatasan akses internet kepada anak.

Kata Kunci: perlindungan hukum, anak, korban, kejahatan siber.

\section{Pokok Muatan}

A. Pendahuluan 317

B. Pembahasan 319

1. Konsep Perlindungan Anak Sebagai Korban Kejahatan Siber Melalui Pendekatan Penal 319

2. Konsep Pembatasan Akses ke Perangkat Komputer 326

C. Penutup 328

D. Ucapan Terima Kasih 328

Hasil Penelitian Doktor Prodi Ilmu Hukum Universitas Muslim Indonesia 2018.

Alamat Korespondensi : hardianto.djanggih@gmail.com. 


\section{A. Pendahuluan}

Negara Republik Indonesia sebagai negara hukum $^{1}$ menganut prinsip-prinsip perlindungan hukum, perlindungan hak asasi manusia bagi warga negaranya, dan prinsip-prinsip demokrasi, termasuk perlindungan kepada anak, sehingga mutlak bagi negara dan pemerintah memberikan perlindungan hukum dan hak asasi manusia kepada anak sebagai bagian dari anak bangsa yang diharapkan menjadi pelanjut cita-cita perjuangan bangsa Indonesia. Indonesia adalah salah satu negara yang telah meratifikasi Konvensi Hak-Hak Anak (KHA) pada Tahun 1990 yang telah disetujui oleh Majelis Umum PBB pada 20 November 1989. Dalam Pasal 4 KHA dinyatakan: "Negara Peserta akan mengambil semua langkah legislatif, administratif dan lain sebagainya untuk pelaksanaan hak-hak yang diakui dalam konvensi." Selain itu dalam Pasal 6 KHA dinyatakan: "Negara Peserta mengakui bahwa setiap anak memiliki hak yang melekat atas kehidupan."

Satu dekade kemudian, tepatnya pada Tahun 2001, Indonesia menyatakan komitmennya terhadap deklarasi Dunia Yang Layak Bagi Anak (A World Fit for Children). Hal ini sesuai dengan ketentuan Konvensi Hak Anak (Convention on the Rights of the Child) yang diratifikasi oleh pemerintah Indonesia melalui Keputusan Presiden Nomor 36 Tahun 1990 dan kemudian juga dituangkan dalam Undang- Undang Nomor 4 Tahun 1979 tentang Kesejahteraan Anak. Selain itu, Undang-Undang Nomor 23 Tahun 2002 tentang Perlindungan Anak yang diubah dengan Undang-Undang Nomor 35 Tahun 2014 tentang Perubahan Undang-Undang Nomor 23 Tahun 2002 tentang Perlindungan Anak dan Undang-Undang Nomor 11 Tahun 2012 tentang Sistem Peradilan Pidana Anak semuanya sama-sama mengemukakan prinsip-prinsip umum perlindungan anak yaitu non diskriminasi, kepentingan terbaik bagi anak, kelangsungan hidup dan tumbuh kembang serta menghargai partisipasi anak. $^{2}$

Spesifik terkait perlindungan hukum terhadap anak, negara memberikan perhatian dengan mengesahkan Undang-undang Nomor 35 Tahun 2014 yang merupakan Perubahan atas Undang-undang Nomor 23 Tahun 2002 mengenai Perlindungan Anak. Perubahan tersebut adalah untuk mempertegas tentang pentingnya pemberatan sanksi pidana dan juga denda bagi pelaku kejahatan terhadap anak untuk memberikan efek jera, serta untuk mendorong adanya langkah konkret untuk memulihkan kembali secara fisik, psikis dan juga sosial anak sebagai korban dan atau anak sebagai pelaku kejahatan sebagai langkah antisipatif supaya anak sebagai korban atau sebagai pelaku tidak menjadi pelaku kejahatan yang sama di kemudian hari. $^{3}$

Aspek perkembangan globalisasi melalui media siber telah diatur pula dalam UndangUndang Nomor 11 Tahun 2008 Tentang Informasi dan Transaksi Elektronik sebagai awal tonggak pembangunan hukum teknologi informasi di Indonesia. Namun, kehadirannya belum menjawab problematika yang ada. Hal yang mendasar karena alasan perkembangan dinamika teknologi informasi yang berkembang cukup pesat sehingga Undang-Undang Nomor 11 Tahun 2008 telah dilakukan judicial review di Mahkamah Konstitusi. Oleh karena itu, sebagai respon pemerintah terhadap perkembangan teknologi informasi, Undang-Undang Nomor 11 Tahun 2008 dalam perkembangannya diubah dengan UndangUndang Nomor 19 Tahun 2016 Tentang Perubahan Undang-Undang Nomor 11 Tahun 2008. ${ }^{4}$ Lahirnya hukum ITE disebabkan adanya aspek hukum yang dilakukan oleh subjek hukum yang memanfaatkan internet mulai pada saat "online" hingga memasuki dunia maya.

\footnotetext{
Amandemen Ketiga Undang-Undang Dasar Negara Republik Indonesia Tahun 1945, Pasal 1 ayat (3) Negara Indonesia adalah negara hukum. Pendapat Ridwan Mansur dikutip dalam Nevey Varida Ariani, "Implementasi Undang-Undang Nomor 11 Tahun 2012 Tentang Sistem Peradilan Anak Untuk Melindungi Kepentingan Anak”, Jurnal Media Hukum, Vol. 21, No. 1, 2014, hlm.108-109.

Penjelasan Undang-Undang Republik Indonesia Nomor 35 Tahun 2014 Tentang Perubahan Atas Undang-Undang Nomor 23 Tahun 2002 tentang Perlindungan Anak (Lembaran Negara Republik Indonesia Tahun 2014 Nomor 297, Tambahan Lembaran Negara Republik Indonesia Nomor 5606).
} 
Pemanfaan siber oleh anak telah membawa perubahan sosial yang mendasar dalam kehidupan masyarakat yang sangat berpengaruh terhadap nilai dan perilaku anak. Penyimpangan tingkah laku atau perbuatan melanggar hukum yang dilakukan oleh anak, antara lain, disebabkan oleh faktor di luar diri anak tersebut. ${ }^{5}$ Data Direktorat Tindak Pidana Siber Mabes Polri selama 5 (Lima) Tahun dari tahun 2012 sampai dengan Tahun 201 mencatat bahwa kejahatan siber yang mengakibatkan anak sebagai korban dalam bentuk kejahatan child pornografi tahun 2012 tidak ada kasus, tahun 2013 terdapat 1 kasus dan mampu diselesaikan, tahun 2014 terdapat 8 kasus, hanya 5 kasus yang mampu diselesaikan, tahun 2015 terdapat 29 kasus, hanya 1 kasus yang mampu diselesaikan, dan tahun 2016 terdapat 5 kasus dan tidak ada kasus yang mampu diselesaikan. ${ }^{6}$ Komisi Perlindungan Anak (KPAI) juga mengungkap data dari Tahun 2011 sampai dengan Tahun 2016. KPAI menemukan bahwa bentuk kejahatan pornografi dan cyber crime pada Tahun 2011 terdapat 188 kasus, Tahun 2012 terdapat 175 kasus, Tahun 2013 terdapat 247 kasus, Tahun 2014 terdapat 322 kasus, Tahun 2015 terdapat 463 kasus dan Tahun 2016 terdapat 497 kasus. Adapun data dari KPAI menunjukkan bahwa terjadi peningkatan kejahatan siber yang menimpa anak. ${ }^{7}$

Asosiasi Jasa Pengguna Internet Indonesia (APJI) mengungkap hasil surveynya yang dirilis Tahun 2016 terhadap anak pengguna internet. Hasil survey menunjukkan $76,4 \%$ tidak aman berinternet bagi anak. Hal ini disebabkan karena internet atau teknologi informasi merupakan instrumen instrumen perbuatan pidana yang sangat potensial, dan kedua menunjukkan perlunya untuk segera membenahi sektor hukum bidang perlindungan anak sebagai korban kejahatan siber di Indonesia. ${ }^{8}$

Terkait adanya fenomena tersebut, perlu dirumuskan kebijakan hukum pidana sebagai upaya untuk melindungi adanya dari perkembangan pemanfaatan media siber, membutuhkan suatu pengkajian yang sangat mendalam, menyangkut aspek filosofis, yuridis, sosiologis dan sebagainya. Teknologi informasi sekarang ini sangat strategis dan berdampak luas terhadap aktifitas kehidupan manusia oleh karena itu dibutuhkan pengaturan secara khusus dengan dibentuknya suatu undangundang yang dapat menanggulangi kejahatan terhadap teknologi informasi. Hal ini sejalan dengan pendapat Fawzia Cassim yang mengatakan bahwa hal demikian kebutuhan munculnya kejahatan siber untuk diberlakukannya undang-undang siber khusus untuk menanganinya. ${ }^{9}$

Dari fakta emipiris tersebut dan dengan payung hukum saat ini, tentunya perlindungan anak korban kejahatan siber harus menjadi perhatian serius pemerintah, dengan langkah-angkah penanganan yang tepat untuk melindungi anak dari kejahatan siber. Langkah-langkah tersebut adalah mengkriminalisasi beberapa perbuatan yang berindikasi bagi timbulnya kejahatan siber dengan sasaran anak sebagai korban yang salah satu bentuk kejahatannya adalah kejahatan seksual online anak.

Kriminalisasi merupakan proses penetapan suatu perbuatan sebagai yang dilarang dan diancam dengan pidana bagi siapa saja yang melanggar larangan tersebut. Kriminalisasi ini berakhir dengan terbentuknya undang-undang yang melarang dan mengancam dengan pidana dilakukannya perbuatan-perbuatan tersebut. Aspek krusial dalam kriminalisasi adalah menentukan kriteria atau ukuran bagi pembentuk undang-undang dalam

\footnotetext{
Hardianto Djanggih, et al, “Urgency Legal Aspects Of Growth Information Technology In Indonesia”, Makalah, 12 th ADRI 2017 International Multidiciplinary Conference, Bogor, 30 Maret-1 April 2017, hlm. 85.

Nevey Varida Ariani, Op.cit., hlm. 108.

Data bersumber dari Direktorat Tindak Pidana Siber Bareskrim Polri 2017 yang didapatkan penulis.

Data bersumber dari Komisi Perlindungan Anak Indonesia (KPAI) tahun 2011-2016 yang didapatkan penulis.

Kementerian Komunikasi dan Informatika Republik Indonesia, "Penetrasi dan Perilaku Pengguna Internet Indonesia", https://aptika.kominfo. go.id/index.php/berita/274-rilis-hasil-survei-penetrasi-dan-perilaku-pengguna-internet-indonesia-tahun-2018, diakses Tanggal 20 Desember 2017.

Fawzia Cassim, "Addressing the Challenge sposed by Cybercrime: A South African Pespective", Journal of International Commercial Law and Technology, Vol. 5, Issue 3, 2010, hlm. 118.
} 
hal apa suatu perbuatan dinyatakan sebagai tindak pidana.

Dalam rangka menanggulangi kejahatan diperlukan berbagai sarana sebagai reaksi yang dapat diberikan kepada pelaku kejahatan, berupa sanksi pidana maupun non pidana, yang dapat diintegrasikan satu dengan lainnya. Apabila sarana pidana dianggap relevan untuk menanggulangi kejahatan, berarti diperlukan konsepsi politik hukum pidana, yakni mengadakan pemilihan untuk mencapai hasil perundang-undangan pidana yang sesuai dengan keadaaan dan situasi pada suatu waktu dan untuk masa-masa yang akan datang.

Berdasarkan latar belakang diatas, penulisan ini memiliki dua rumusan masalah yaitu, Pertama, Bagaimanakah konsep perlindungan bagi anak sebagai korban kejahatan siber melalui pendekatan penal? Kedua, Bagaimanakah konsep perlindungan bagi anak sebagai korban kejahatan siber melalui pendekatan non penal?

\section{B. Pembahasan}

1. Konsep Perlindungan Anak Sebagai Korban Kejahatan Siber Melalui Pendekatan Penal

Pendekatan penal merupakan cara memanfaatkan sarana pidana atau sanksi pidana. Pendekatan ini merupakan pendekatan yang paling tua dalam pidana karena pendekatan ini menurut Gene Kassebaum sebagaimana dikutip Barda Nawawi dan Muladi merupakan pendekatan yang umurnya setua peradaban manusia, sehingga sarana penal merupakan older philosophy of crime control. ${ }^{10}$

Penggunaan sarana pidana berarti menggunakan upaya paksa yang dimiliki hukum pidana melalui sistem peradilan pidana. Menurut Mardjono Reksodiputro, sistem peradilan pidana adalah sistem pengendalian kejahatan yang terdiri dari lembaga kepolisian, kejaksaan, pengadilan, dan pemasyarakatan. ${ }^{11}$ Mengenai sarana penal dalam suatu peradilan, Barda Nawawi Arief berpendapat bahwa sistem peradilan pidana pada hakikatnya identik dengan sistem penegakan hukum pidana ataupun sistem kekuasaan kehakiman di bidang hukum pidana, terpadu diimplementasikan dalam 4 (empat) sub-sistem kekuasaan, yaitu yaitu kekuasaan penyidikan, penuntutan, kekuasaan mengadili atau menjatuhkan pidana dan kekuasaan eksekusi atau pelaksanaan pidana. ${ }^{12}$

Menurut Phillips dalam bukuya A First Book English Law, sebagaimana dikutip oleh Andi Hamzah, yang dipandang sebagai tujuan pemidanaan yang berlaku sekarang ialah variasi dari bentuk-bentuk penjeraan (detterent), baik ditujukan kepada pelanggaran hukum itu sendiri maupun kepada mereka yang mempunyai potensi menjadi penjahat, perlindungan kepada masyarakat dari perbuatan jahat, perbaikan (reformasi) kepada penjahat. Hal tersebut terakhir yang paling modern dan populer dewasa ini, bukan saja bertujuan memperbaiki kondisi pemenjaraan tetapi juga mencari alternatif lain yang bukan bersifat pidana dalam membina pelanggar hukum. ${ }^{13}$

Pertanyaan yang sering dimunculkan para pakar hukum pidana dalam berbagai seminar adalah pertanyaan tentang bagaimana hukum pidana sebaiknya atau seharusnya pada masa ini dan masa yang akan datang. Pertanyaan ini berkaitan dengan bidang politik hukum pidana (penal policy), yaitu bagaimana sebaiknya hukum pidana itu dibuat, disusun dan digunakan untuk mengatur atau mengendalikan tingkah laku manusia dalam masyarakat. khususnya guna menanggulangi kejahatan yang dilakukan baik oleh anggota masyarakat maupun oleh penguasa. ${ }^{14}$

10 Barda Nawawi Arief dan Muladi, 1984, Pidana dan Pemidanaan, Badan Penyediaan Bahan Kuliah Fakultas Hukum UNDIP, Semarang, hlm. 149.

11 Merdjono Reksodiputro, "Sistem Peradilan Indonesia (Melihat Kejahatan dan Penegakan Hukum Dalam Batas Toleransi)", Makalah, Pengukuhan Guru Besar Ilmu Hukum pada Fakultas Hukum Universitas Indonesia, Jakarta.1993, hlm. 1.

12 Barda Nawawi Arief, 2003, Kapita Selekta Hukum Pidana, Citra Aditya, Bandung. hlm. 9.

13 Andi Hamzah, 1986, Sistem Pidana dan Pemidanaan Indonesia dari Retribusi ke Reformasi, Cetakan Ke-1, Pradnya Paramita, Jakarta.hlm. 16.

14 Faizin Sulistio, et al., "Alternatif Model Pemidanaan Tindak Pidana Pornografi Siber”, Jurnal Arena Hukum, Vol. 9, No. 3, 2016, hlm. 359. 
Upaya-upaya untuk mencari alternatif sanksi dari pidana perampasan kemerdekaan jangka pendek ini juga didukung oleh Perserikatan Bangsa-Bangsa (PBB). Dalam Kongres ke-2 PBB mengenai "The Prevention of Crime and Treatment of Ofenders" tahun 1960 di London merekomendasikan bahwa prakteknya penghapusan menyeluruh pidana penjara jangka pendek tidaklah mungkin. pemecahannya yang realistis hanya dapat dicapai dengan mengurangi jumlah penggunaanya. Pengurangan berangsur-angsur itu dengan meningkatkan bentuk-bentuk pengganti/ alternatif (pidana bersyarat, pengawasan/probation, denda, pekerjaan di luarlembaga. dan tindakantindakan lain yang tidak mengandung perampasan kemerdekaan. ${ }^{15}$

Pertanggungjawaban pidana serta sanksi pidana itu sendiri merupakan suatu masalah pokok dalam hukum pidana. Sudarto mengatakan ada beberapa hal yang dapat digunakan sebagai kriteria apakah suatu perbuatan dapat diberi suatu ancaman pidana atau tidak. Hal-hal tersebut adalah:

a. Penggunaan hukum pidana harus berusaha mewujudkan masyarakat adil makmur yang merata materiil dan spirituil berdasarkan Pancasila dalam wadah Negara Kesatuan Republik Indonesia. Hukum pidana bertujuan untuk menanggulangi kejahatan dan sekaligus pengugeran terhadap tindakan penanggulangan itu sendiri.

b. Perbuatan yang hendak dikehendaki yaitu yang mendatangkan kerugian baik bagi masyarakat maupun bagi diri sendiri pelakunya.

c. Usaha mencegah suatu perbuatan dengan mempergunakan sarana hukum pidana, perlu disertai dengan perhitungan biaya yang harus dikeluarkan dan hasil yang diharapkan akan dicapai (costand benefit principle).

d. Pembuatan peraturan hukum pidana perlu memperhatikan kemampuan daya kerja dari badan-badan penegak hukum (over belasting), yang justru akan mengakibatkan efek dari suatu peraturan itu menjadi berkurang. ${ }^{16}$

Romli Atmasasmita menyatakan bahwa Perserikatan Bangsa-Bangsa memberikan perhatian yang cukup besar pada bangsa-bangsa di dunia dalam upaya penanggulangan kejahatan. Masalah sistem peradilan pidana dan penanggulangan kejahatan juga tidak luput dari perhatiannya. Perserikatan Bangsa-Bangsa memandang masalah sebagai bagian dari masalah yang lebih luas dan kompleks sifatnya yaitu masalah sosial, ekonomi, budaya dan politik. ${ }^{17}$

Kejahatan merupakan perilaku menyimpang yang akan senantiasa ada dan melekat pada setiap bentuk masyarakat. Kejahatan merupakan masalah sosial yang paling tua oleh sebab itu harus ditanggulangi. Dilihat dari akibatnya kejahatan dapat menganggu atau merusak dan merintangi tercapainya tujuan nasional dan juga mencegah penggunaan optimal dari sumber-sumber nasional Sudarto menyatakan bahwa penggunaan sarana penal dalam menanggulangi kejahatan tidak dapat dilepaskan keterkaitannya dengan kebijakan hukum pidana atau politik hukum pidana (criminal law policy). Sehubungan dengan hal tersebut, maka Soedarto mengemukakan bahwa melaksanakan politik hukum pidana berarti mengadakan penilaian dan pemilihan untuk mencapai hasil perundangundangan pidana yang paling baik, dalam arti memenuhi syarat keadilan dan daya guna. ${ }^{18}$

Pernyataan Sudarto sangat beralasan kaitannya dengan fenomenan kejahatan siber dewasa ini yang salah satunya mengakibatkan anak sebagai korban, sehingga untuk menanggulanginya harus dengan perumusan dan penggunaan perundangundangan secara tepat agar tujuan dari hukum itu bisa tercapai. Di Indonesia, perlindungan anak dari pengaruh buruk pemanfaatan siber dapat ditemukan dalam berbagai perundang-undangan, yakni:

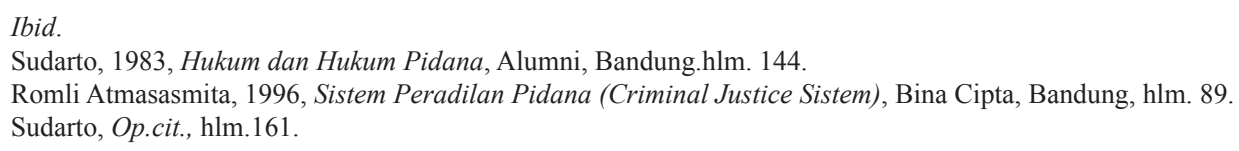


1. Pasal 15 Undang-Undang Nomor 44 Tahun 2008 tentang Pornografi yang menyatakan bahwa "Setiap orang berkewajiban melindungi anak dari pengaruh pornografi dan mencegah akses anak terhadap informasi pornografi." 19

2. Pasal 43 Undang-Undang Nomor 33 Tahun 2009 tentang Perfilman menegaskan bahwa "Pelaku usaha perfilman dilarang melakukan sulih suara film impor ke dalam bahasa Indonesia, kecuali film impor untuk kepentingan pendidikan dan/atau penelitian." 20

3. Pasal 38 ayat (3) Undang-Undang Nomor 32 Tahun 2002 tentang Penyiaran menyatakan bahwa "Isi siaran wajib memberikan perlindungan dan pemberdayaan kepada khalayak khusus, yaitu anak-anak dan remaja [...]." ${ }^{621}$

4. Pasal 27 Undang-Undang Nomor 19 Tahun 2016 tentang Perubahan Undang-Undang Nomor 11 Tahun 2008 tentang Informasi \& Transaksi Elektronik yang menegaskan larangan mendistribusikan dan/atau mentransmisikan dan/atau membuat dapat diaksesnya Informasi Elektronik dan/atau Dokumen Elektronik yang memiliki muatan yang melanggar kesusilaan dan perjudian. ${ }^{22}$

5. Pasal 59 Undang-Undang Nomor 35 Tahun 2014 Tentang Perubahan Undang-Undang Nomor 23 Tahun 2002 tentang Perlindungan Anak yang menyatakan bahwa "Pemerintah dan lembaga negara lainnya berkewajiban dan bertanggung jawab untuk memberikan perlindungan khusus kepada anak dalam situasi darurat, anak yang berhadapan dengan hukum, anak dari kelompok minoritas dan terisolasi, anak tereksploitasi secara ekonomi dan/atau seksual, anak yang diperdagangkan, anak yang menjadi korban penyalahgunaan narkotika, alkohol, psikotropika, dan zat adiktif lainnya (napza), anak korban penculikan, penjualan dan perdagangan, anak korban." 23

Ketersediaan perundang-undangan tersebut dalam melindungi anak dari pemanfaatan siber, menurut penulis belumlah dapat menjangkau adanya perkembangan kejahatan siber yang mengakibatkan anak sebagai korban. Alasan penulis adalah masih adanya bentuk-bentuk kejahatankejahatan siber yang perlu dikriminalisasi dan perlu juga merumuskan bentuk hukuman yang tepat bagi pelaku kejahatan siber yang mengakibatkan anak sebagai korban. Hal tersebut sangat beralasan pula sebagaimana dikaitkan dengan pernyataan Ahmad Taufan Damanik bahwa: "The internet further supports the child sex tourism industry by providing patrons o fthe setours a means by which toeasily connect with like-minded other sthrough put the world". ${ }^{24}$

Terkait dengan kejahatan siber, perlu diingat kembali bahwasannya sifat dari kejahatan ini sendiri adalah anonymity. Media siber (Internet) memberikan kemudahan bagi pelaku kejahatan siber karena pada hakikatnya pelaku tidak mudah terungkap atau terdeteksi dan ditelusuri, dan menggunakan ruang-ruang chatting, facebook, maupun forum diskusi terbuka lainnya.

19 Pasal 15 Undang-Undang Nomor 44 Tahun 2008 tentang Pornografi (Lembaran Negara Republik Indonesia Tahun 2008 Nomor 181 , Tambahan Lembaran Negara Republik Indonesia Nomor 4928).

20 Pasal 45 Undang-Undang Nomor 33 Tahun 2009 tentang Perfilman (Lembaran Negara Republik Indonesia Tahun 2009 Nomor 141, Tambahan Lembaran Negara Republik Indonesia Nomor 5060).

21 Pasal 38 ayat (3) Undang-Undang Nomor 32 Tahun 2002 tentang Penyiaran (Lembaran Negara Republik Indonesia Tahun 2002 Nomor 139 , Tambahan Lembaran Negara Republik Indonesia Nomor 4252).

22 Pasal 27 Undang-Undang Nomor 19 Tahun 2016 tentang Perubahan Atas Undang-Undang Nomor 11 Tahun 2008 tentang Informasi dan Transaksi Elektronik (Lembaran Negara Republik Indonesia Tahun 2016 Nomor 251, Tambahan Lembaran Negara Republik Indonesia Nomor 5952).

23 Pasal 59 Undang-Undang Nomor 35 Tahun 2014 Tentang Perubahan Undang-Undang Nomor 23 Tahun 2002 tentang Perlindungan Anak (Lembaran Negara Republik Indonesia Tahun 2014 Nomor 297, Tambahan Lembaran Negara Republik Indonesia Nomor 5606).

24 Ahmad Taufan Damanik, "The Efforts of ASEAN-ACWC in Addressing the Trend of Sexual Crimes Against Children Online", Makalah, Conference on Sexual Crime against Children Online: Law Enforcement and Regional Cooperation, Jakarta, 29 - 30 October 2012. 


\section{a. Konsep Pemidanaan Denda minimum Khusus}

Sistem minimum khusus ataupun jenis alternatif pidana yang lain dapat dilakukan dengan merujuk ketentuan pasal 103 KUHP yaitu selama undang-undang di luar KUHP mengatur secara khusus tentang ketentuan tata cara atau pedoman pemidanaan. Pidana denda dengan minimum khusus dilakukan terhadap perbuatan yang dianggap sangat berbahaya. ${ }^{25}$ Menurut penulis adanya tindak pidana siber dengan sasaran anak sebagai korban termasuk dalam kejahatan yang sangat berbahaya.

Formulasi penetapan jumlah denda dapat dirumuskan hanya kategori dendanya saja sehingga mudah disesuaikan dengan perkembangan situasi. Hal ini mengingat pidana denda berbeda dengan jenis tindak pidana pokok lainnya karena merupakan jenis pidana yang bernilai uang dan mempunyai nilai ekonomi. Dengan demikian pidana denda mudah berubah nilainya karena pengaruh perkembangan moneter maupun perkembangan ekonomi suatu masyarakat baik dilihat secara nasional maupun internasional. ${ }^{26}$ Oleh karena itu, ancaman minimum khusus ini tidak diancamkan pada setiap jenis tindak pidana, tetapi diancamkan pada jenis tindak pidana yang dipandang menimbulkan disparitas pidana dan membahayakan atau sangat merugikan masyarakat yang diperberat oleh akibatnya.

Permasalahan yang sering terjadi adalah beberapa peraturan perundangundangan memuat ancaman atau formulasi pidana denda dengan sistem minimal khusus dan dalam jumlah yang cukup besar namun mengenai detail tata cara atau pedoman pemidanaan tidak diatur. Hal yang seharusnya diatur mencakup tata cara pembayaran, apakah dengan tunai atau tidak, kapan batas akhir dari pembayaran, serta konsekuensi apa saja yang bisa dijatuhkan apabila jumlah denda yang dibayarkan tidak sesuai dengan jumlah yang ditetapkan atau dikenakan. Denda ini sangat cocok diterapkan pada tindak pidana siber yang menyasar anak sebagai korban.

\section{b. Konsep Pidana Ganti Kerugian Kepada Korban}

Upaya perlindungan terhadap korban tindak pidana merupakan upaya pemulihan kerugian yang telah didapatkan oleh korban. Hal tersebut akan lebih termaknai apabila korban dilibatkan langsung dalam proses penyelesaian perkara pidana. Penegakan hukum merupakan upaya pembangunan yang berkesinambungan yang bertujuan mewujudkan kehidupan berbangsa dan bernegara yang aman, tentram tertib serta dinamis dalam lingkungan pergaulan dunia yang independen. ${ }^{27}$

Tujuan pemberian ganti rugi tidak lain untuk mengembangkan keadilan dan kesejahteraan korban sebagai anggota masyarakat dengan tolok ukur pelaksanaannya, korban diberikan hak dan kewajiban untuk dikembangkan sebagai orang (anak juga orang). Oleh karena itu, diperlukan peraturan yang tegas, sederhana, dan mudah dimengerti sehingga dapat dihindari diskriminasi dalam penerapan oleh penegak hukum dan intimidasi dari pihakpihak tertentu yang lebih memperburuk kondisi korban dalam penderitaan yang berkepanjangan.

Pidana ganti kerugian merupakan suatu pidana yang mewajibkan seseorang yang telah bertindak merugikan orang lain

Faizin Sulistio, et al., Op.cit., hlm. 361.

Barda Nawawi Arif, et al., 1992, Teori-Teori dan Kebijakan Pidana, Alumni, Bandung, hlm. 182.

Thantawi, et al., "Perlindungan Korban Tindak Pidana Siber Crime Dalam Sistem Hukum Pidana Indonesia", Jurnal Ilmu Hukum, Vol. .2, No. 1, 2014, hlm. 39. 
untuk membayar sejumlah uang ataupun barang pada orang yang dirugikan. ${ }^{28}$ Dalam perkembangan peraturan perundangundangan di Indonesia, pidana ganti kerugian tidak hanya menjadi domain dari hukum perdata, tetapi juga telah masuk ke dalam hukum pidana. Perkembangan ini terjadi karena semakin meningkatnya perhatian masyarakat dunia terhadap akses korban tindak pidana dalam sistem peradilan pidana. ${ }^{29}$

Ketentuan pidana ganti kerugian dapat ditelusuri dalam hukum berbagai hukum adat di Indonesia baik dalam hukum adat yang tidak tertulis maupun dalam ketentuanketentuan yang tertulis. Sebagai contoh pada zaman Kerajaan Majapahit terdapat Kitab Adigama atau agama yang memuat pidana ganti kerugian sebagai bentuk pidana pokok. Kitab ini memiliki pidana Ganti Kerugian dengan nama panglicawa, putukucawa dan pamidara. Selain itu, dikenal pula pidana tambahan berupa uang pembeli obat yang disebut patibajampi atau patukutamba. Pidana ganti kerugian ini dibebankan pada tindak pidana pencurian dan dusta yang menimbulkan korban, kelalaian yang menyebabkan matinya orang, pembunuhan terhadap orang yang tidak berdosa, merusak milik orang lain dan sebagainya. Sedangkan pidana tambahan berupa uang pembeli obat dibebankan pada pelaku jika pihak korban menderita luka-luka.

Pidana ganti kerugian dalam perspektif hukum adat merupakan suatu kewajiban yang harus dibayar karena adanya tuntutan dari pihak yang telah dirugikan. Tujuannya agar masalah yang terjadi dapat diselesaikan dengan damai. Selain itu, terdapat pidana
Ganti Kerugian untuk mengadakan selamatan desa yang bertujuan untuk mengembalikan keseimbangan masyarakat. ${ }^{30}$

Selain ganti kerugian materiil, dalam hukum adat dikenal pula ganti kerugian yang immateriil seperti paksaan menikah pada gadis yang telah dicemarkan. ${ }^{31}$ Fakta dari hukum adat tersebut telah menunjukkan bahwa hukum Indonesia sejak jaman dahulu telah mengenal pidana ganti kerugian yang harus dibayar oleh orang yang telah melakukan perbuatan yang dipandang tercela oleh masyarakat kepada korban (orang yang menderita ataupun keluarga korban). Ganti kerugian ini dilakukan agar terciptanya perdamaian kembali ataupun agar keseimbangan masyarakat pulih kembali.

Keberadaan KUHP yang merupakan warisan Belanda yang dibentuk pada abad ke-19, tidak mengenal pidana ganti kerugian. Hal ini dikarenakan paradigma pada masa pembentukannya lebih kepada pembalasan (retributif). Namun demikian, dalam Pasal 14c KUHP terdapat ketentuan pidana bersyarat yang menyatakan bahwa hakim dalam menjatuhkan pidana bersyarat terhadap pelaku tindak pidana selain menentukan syarat umum dapat pula sekaligus menjatuhkan syarat khusus berupa ganti kerugian yang harus dipenuhi sebelum masa percobaannya berakhir.

Terlepas dari KUHP, sebenarnya dalam hukum pidana positif yang lain ketentuan tentang ganti kerugian juga dikenal. Undangundang Tindak Pidana Korupsi dalam Pasal 34 mengatur tentang pidana tambahan berupa pembayaran uang pengganti yang jumlahnya sebanyak-banyaknya sama dengan harta benda yang diperoleh dari korupsi. Dalam

28 Jeremy Bentham, 2006, Teori Perundang-Undangan Prinsip-Prinsip Legislasi, Hukum Perdatadan Hukum Pidana, Penerbit Nusamedia dan Penerbit Nuansa, Bandung, ,hlm. 316.

29 Maulana, et al., 1967, Perundang-undangan Majapahit, Bhatara, Jakarta. hlm. 26-33.

$30 \quad$ Faizin Sulistio dan Nazura Abdul Manaf, Op.cit., hlm. 362.

31 Hilman Hadikusuma, 1984, Hukum Pidana Adat, Alumni, Bandung.hlm. 24. 
hal ini ganti kerugian diberikan pada negara karena negara adalah merupakan korban (collective victim). Dalam konteks pornografi siber maka sanksi ganti rugi ini juga dapat berupa korban kolektif yang diwakili negara dan penggunaannya untuk rehabilitasi mental korban pornografi. Selain itu, ganti kerugian juga dapat diberikan kepada orang yang secara langsung menjadi korban pornografi siber.

Sanksi ganti kerugian sebagaimana telah dinyatakan di atas adalah sanksi yang ditujukan untuk melindungi korban tindak pidana. Selain itu, masih ada beberapa manfaat lain yang memberikan nilai lebih pada sanksi ganti kerugian bila dimasukkan ke dalam KUHP yang baru.

Perlindungan terhadap korban kejahatan menjadi fokus perhatian masyarakat dunia sekarang ini. Ada dua cara yang berkembang dewasa ini yaitu prosedural rights model dan service model. Model yang pertama menghendaki diikutsertakannya korban dalam proses peradilan baik terlibat langsung dalam sidang pengadilan ataupun di belakang sidang ikut mempertimbangkan sanksi yang akan dijatuhkan pada pelaku tindak pidana. Sedangkan model yang kedua adalah melayani korban tindak pidana, dengan menghilangkan atau mengurangi penderitaan korban.

Model yang kedua ini biasanya menggunakan ganti rugi sebagai sarana. Dari dua cara tersebut nampaknya service model lebih tepat untuk dilaksanakan karena prosedural rights model akan sangat menghambat kelancaran proses peradilan yang dikehendaki yaitu cepat tepat adil dan biaya ringan. Sebaliknya dengan menerima service model maka harus memasukkan sanksi ganti kerugian ke dalam hukum pidana. Dengan demikian jika sanksi ganti kerugian nantinya menjadi bagian KUHP, maka hukum pidana Indonesia akan diterima oleh dunia internasional. Selain itu, hal ini akan menunjukan bahwa KUHP bersifat modern karena telah memperhatikan perbuatan, pelaku dan korban (daad-daderstraftrecht dan victim). Dalam menjatuhkan pidana pada seseorang tentu harus dipertimbangkan pula tujuan pemidanaan. Ada banyak tujuan Pidana yang dikenal tetapi konsep Rancangan Undang-undang Hukum Pidana dalam Pasal 47 menentukan tujuan pemidanaan adalah untuk:

1. Mencapai dilakukan tindak pidana dengan menegakkan norma hukum demi pengayoman masyarakat;

2. Memasyarakatkan terpidana dengan mengadakan pembinaan sehingga menjadikan orang yang baik dan berguna;

3. Menyelesaikan konflik yang ditimbulkan oleh tindak pidana, memulihkan keseimbangan, dan memdatangkan rasa damai dalam masyarakat;

4. Membebaskan rasa bersalah pada terpidana.

Melihat keempat tujuan ini maka sanksi ganti kerugian jelas memiliki tujuan yang lebih dekat pada upaya penyelesaian konflik dan membebaskan rasa bersalah pada terpidana. Sanksi ganti kerugian memang dari sejarah keberadaannya ditujukan untuk menyelesaikan konflik. Adanya ganti kerugian maka akan dianggap bahwa suatu peristiwa tidak pernah terjadi. Dengan demikian, hal ini akan mengembalikan sistem kepercayaan korban dalam menghadapi kehidupan dan membebaskan rasa bersalah terpidana yang dapat membuatnya tertekan serta merugikan dirinya atau masyarakat. Selain itu, dengan diterimanya uang ganti kerugian tersebut oleh korban berarti secara psikologis korban dapat dikatakan telah memberikan maaf pada pelaku tindak pidana tersebut. Dengan demikian, sanksi ganti kerugian sangat berperan sebagai jembatan 
perdamaian yang menghindarkan pelaku kejahatan dari sanksi pokok yang berat dan menghindarkan negara mengeluarkan dana lebih banyak untuk menanggulang kejahatan.

\section{Konsep Perlindungan Hukum Bagi Anak Korban Kejahatan Siber Melalui Pendekatan Non Penal}

Upaya penanggulangan kejahatan tidak hanya dengan sarana "penal" yang bersifat represive (penindakan/pemberantasan), tetapi juga dilakukan dengan sarana non penal (bukan/diluar hukum pidana), yang bersifat preventive (pencegahan/ penangkalan/pengendalian). ${ }^{32}$ Pendekatan non penal memiliki tujuan utama untuk memperbaiki kondisikondisi sosial tertentu, namun secara tidak langsung mempunyai pengaruh preventif terhadap kejahatan. Menurut Barda Nawawi Arief, pendekatan non penal dalam politik kriminal memiliki posisi yang sangat strategis dan memegang posisi kunci yang harus diintensifikasikan dan diefektifkan apabila pendekatan ini mengalami kegagalan dalam penggarapannya justru akan berakibat fatal bagi usaha menaggulangi kejahatan. ${ }^{33}$

Kongres Perserikatan Bangsa-Bangsa (PBB) mengenai The Prevention of Crime and Thetreatment of Offenders mengamanatkan bahwa upaya preventif untuk menanggulangi kejahatan dapat dilakukan dengan dasar penghapusan sebab-sebab kondisi yang menyebabkan timbulnya kejahatan. Upaya demikian harus merupakan strategi pokok/ mendasar dalam pencegahan kejahatan (the basic crime prevention strategy). ${ }^{34}$

$$
\text { Penanggulangan kejahatan melalui }
$$
sarana non penal dilakukan karena sarana penal memiliki keterbatasan-keterbatasan sebagaimana dikemukakan oleh para pakar antara lain: ${ }^{35}$

1. Rubin, menyatakan bahwa pemidanaan apapun hakikatnya dimaksudkan untuk menghukum atau memperbaiki hanya sedikit atau tidak mempunyai pengaruh terhadap masalah kejahatan;

2. Karl O. Cristiansen, menyatakan bahwa kita mengetahui pengaruh pidana penjara terhadap di pelanggar, tetapi pengaruh-pengaruhnya terhadap masyarakat secara keseluruhan (general prevention) merupakan terra in cognita atau suatu wilayah yang tidak diketahui (unknownterritory);

3. S. R. Brody, menyatakan bahwa dari Sembilan Penelitian mengenai pemidanaan, lima diantaranya menyatakan bahwa lamanya waktu yang dijalani di dalam penjara tampaknya tidak berpengaruh pada adanya penghukuman kembali (reconviction).

4. Bassioni pernah menegaskan bahwa kita tidak tahu atau tidak pernah tahu secara pasti metode-metode tindakan (treatment) apa yang paling efektif untuk mencegah dan memperbaiki atau mengetahui seberapa jauh efektivitas setiap tindakan itu untuk menjawab masalah-masalah secara pasti, kita harus mengetahui sebabsebab kejahatan dan untuk mengetahui hal ini tidak memerlukan pengetahuan yang lengkap mengenai etiologi tingkah laku manusia.

Mendasari keterbatasan-keterbatasan sarana penal tersebut menunjukkan adanya kelemahan atau ketidakmampuan hukum pidana dari sudut hakikat berfungsinya atau bekerjanya hukum (sanksi) pidana itu sendiri. Sedangkan apabila ditinjau dari kejahatan sebagai masalah sosial, maka banyak faktor yang menyebabkan terjadinya suatu kejahatan. Faktor penyebab terjadinya kejahatan tersebut sangat kompleks dan berada di luar jangakauan hukum pidana. Wajarlah hukum pidana mempunyai keterbatasan kemampuan untuk menanggulangi seperti yang pernah dikemukakan Sudarto bahwa penggunaan hukum pidana merupakan penanggulangan suatu gejala (Kuren 
am Symton) dan bukan suatu penyelesaian dengan menghilangkan sebab-sebabnya. ${ }^{36}$

Sekalipun demikian, harus diakui bahwa konsep dan definisinya masih terlalu lemah, sehingga orang cenderung untuk membicarakan pencegahan kejahatan dalam kerangka pendekatan dan model. Secara tradisional, tujuan sistem peradilan pidana bersifat represif dan berkaitan dengan pencegahan kejahatan setelah suatu kejahatan terjadi (after an offence has already accured). Konsep pencegahan kejahatan sendiri memfokuskan diri pada campur tangan sosial, ekonomi, dan pelbagai area kebijakan publik dengan maksud mencegah kejahatan sebelum kejahatan dilakukan (to perevent crime before an offence has been committed.). Telaah tersebut, menarik kiranya bagi penelitian ini untuk menjawab tentang adanya pencegahan kejahatan yang terjadi di media siber melalui pendekatan nonpenal dengan konsep sebagai berikut:

\section{Konsep Pembatasan Akses ke Perangkat Komputer}

Menjaga anak-anak dari bahaya siber pornography adalah hal yang cukup menantang, diperlukan peran dari berbagai pihak tidak hanya orang tua namun juga dari negara, lembagalembaga terkait masalah perlindungan dan lainnya. Banyaknya kejahatan di ruang siber yang menimpa anak-anak merepresentasikan masih rendahnya keamanan siber (siber security) di Indonesia. Saat ini salah satu usaha menjaga keamanan dalam mengakses ruang siber ialahmelalui UU ITE.

Weny Rochmawati menyampaikan bahwa,

Penggunaan internet di kalangan anakanak merupakan sebuah kepentingan yang sangat dibutuhkan. Kepentingan tersebut mencakup kepentingan berupa hiburan maupun akademik. Penggunaan internet menimbulkan hal-hal yang positif seperti anak-anak dapat mencari artikel-artikel tentang tugas-tugas sekolah dan juga mencari situs-situs yang berhubungan dengan fun atau leisure. Anak-anak lebih menyukai untuk membuka situs-situs atau alamat website yang berhubungan dengan kepentingan fun atau leisure dibandingkan dengan yang berhubungan dengan kegiatan akademik di sekolah. Namun demikian, tetap ada anakanak yang memanfaatkan internet untuk kepentingan akademik dengan mengakses sumber informasi yang berupa email. ${ }^{37}$

Puspita Adiyani Candra dalam penelitiannya juga mengemukakan bahwa,

Anak-anak di Indonesia mulai mengenal internet dalam usia yang sangat muda. Kebanyakan mulai mengenal internet pada usia 6-8 tahun, namun tidak sedikit pula yang sudah mulai mengenal internet pada usia yang lebih muda. Bahkan ada yang berkenalan dengan internet saat usianya baru 3 tahun. Mayoritas dari anak-anak mengenal internet melalui perkenalan dalam lingkungan pendidikan informal yaitu rumah lewat orang tua, saudara bahkan neneknya. Lokasi yang paling banyak digunakan untuk mengakses internet pun juga tidak jauh berbeda. Mengakses di rumah menjadi opsi yang paling banyak dipilih berdasarkan penelitian itu. Anak-anak late childhood kebayakan masih tergolong light user dalam menggunakan internet. Artinya, mereka hanya mengakses internet kurang dari 7 jam per minggu. Hanya 9\% diantaranya yang menjagi high user. Kebanyakan, anakanak tersebut mengakses internet dengan durasi yang panjang di akhir pekan. Hal ini menunjukkan bahwa anak-anak generasi ini mempunyai cara yang tidak sama dalam menggunakan leisure time dari generasi sebelumnya yang lebih suka bermain di luar secara fisik. ${ }^{38}$

Semakin banyaknya anak-anak yang mengakses internet tentu membawa kekhawatiran tersendiri. Orang tua tentu khawatir anak-anak akan mengakses situs-situs yang tidak layak. Salah satu yang menjadi perhatian adalah akses terhadap konten pornografi di internet. Hal ini akan sangat

Aminanto, 2017, Politik Hukum Pidana 1, Kertamedia, Jember, hlm.59.

Weny Rochmawati, "Perilaku Pemanfaatan Internet (Internet Utilization of Behavior) (Studi Deskriptif tentang Pemanfaatan Internet untuk KepentinganHiburan dan Akademik di Kalangan Anak-anak di Kota Surabaya)", Jurnal Libri-Net, Vol. 1, No. 1, 2012 , hlm. 12.

38 Puspita Adiyani Candra, "Penggunaan Internet pada Anak-anak Sekolah Usia 6- 12 Tahun di Surabaya", Jurnal Commonline, Vol.1, No. 2, 2013. 
mudah terjadi dengan banyaknya situs pornografi di internet. Sebuah data yang dipublikasikan oleh toptenreviews.com menyebutkan bahwa ada 4,2 juta situs porno di internet dengan jumlah laman porno di internet mencapai 420 juta. Yang mengkhawatirkan, pengakses situs porno di Indonesia juga sangat besar, bahkan Menkominfo menyebutkan bahwa Indonesia adalah pengakses situs pornografi terbesar kedua di dunia. ${ }^{39}$

Penelitian yang dilakukan oleh Kandi Aryani mengungkapkan bahwa,

Remaja menganggap pornografi sebagai sesuatu yang tidak bermoral dan melanggar nilai serta norma yang berlaku di masyarakat Indonesia. Pendapat remaja ini mengacu dan disesuaikan dengan standar moral serta mengikuti pendapat dominan yang berlaku di masyarakat secara umum. Tetapi pendapat ini ternyata menjadi berbeda dan bisa dikatakan tidak sejalan ketika ditanyakan mengenai sikap mereka terhadap pornografi dan keberadaan situ-situs seks di internet. Pornografi dipandang sebagai sesuatu yang tidak bisa dihindari keberadaannya. Remaja memilih bersikap untuk tidak melarang keberadaan pornografi di internet dan menganggapnya sebagai sesuatu yang sah-sah saja, apalagi bagi beberapa remaja, pornografi juga dianggap memberikan manfaat sebagai hiburan atau refreshing. ${ }^{40}$

Saat ini, telah diterbitkan Peraturan Kementerian Komunikasi dan Informatika No 19 Tahun 2014 tentang Penanganan Situs Internet Bermuatan Negatif sebagai respons terhadap faktafakta empiris diatas. Namun demikian, peraturan tersebut dinilai banyak pihak tidak memiliki legitimasi yang jelas. Permen ini mencakup wilayah yang luas dan tidak memliki definisi yang jelas terhadap konten internet berbau negatif. Co-Founder ITC Watch Donny BU menilai, ketidakjelasan prosedur seperti itu juga membatasi hak asasi manusia dalam kebebasan berekspresi dan memperoleh informasi. Bahkan, pembatasan ini bisa menjurus kepada over blocking. ${ }^{41}$

Pembatasankebebasanmenggunakanalat-alat yang berhubungan dengan internet dikembangkan sebagai bentuk hukuman kepada pelaku yang melakukan pornografi siber. Model hukuman ini dikembangkan karena negara menyadari bahwa ada kekhususan tersendiri pada pelaku tindak pidana di alam siber. Pelaku merupakan orang yang mempunyai kelebihan khusus dalam bidang siber. Oleh karena itu beberapa negara seperti di Amerika Serikat, Inggris dan Wales mencoba menerapkan model pemidanaan ini. Biasanya, hukuman kepada pelaku yang berhubungan dengan internet dibagi dalam 3 (tiga) model, yaitu:

1. Pembatasan penggunaan internet atau peralatan komputer yang mampu menghubungkan ke internet.

2. Pembatasan yang memerlukan penggunaan perangkat lunak monitoring.

3. Perangkat yang membutuhkan akses oleh mereka yang berkuasa pada peralatan yang digunakan oleh pelaku.

Tiga bentuk model ini akan digunakan sehingga dapat menyesuaikan pembatasan individu untuk pelaku. Secara konkrit untuk mengurangi penyimpangan perilaku di media siber yaitu dengan menggunakan software yang dirancang khusus untuk melindungi anak.

Pihak pemerintah dalam hal ini Kemenkominfo harus dapat membuat sebuah softwere khusus untuk melindungi anak dari kejahatan di media siber. Lebih lanjut, software tersebut juga bertujuan:

1. Mengurangi kekuatiran ketika anak mengakses internet menggunakan komputer.

2. Melindungi informasi pribadi.

\footnotetext{
39 Masyari Ulinnuha, "Melindungi Anak dari Konten Negatif Internet: Studi Terhadap Perambaan Web Khusus Anak", Jurnal Sawwa, Vol. 8, No. 3, 2013, hlm.344-345

40 Kandi Aryani S., "Penerimaan Remaja terhadap Wacana Pornografi dalam Situs-Situs Seks di Media Online", Jurnal Penelitian Dinamika Sosial, Vol. 7, 2008

41 Beritasatu, "Peraturan Kominfo tentang Pembatasan Akses Internet dinilai Langkahi Hukum", http://www.beritasatu.com/hukum/201797peraturan-kominfo-tentang-pembata-san-akses-internet-dinilai-langkahi-hukum.html, diakses tanggal 2 Nopember 2017.
} 
3. Mengetahui bagaimana anak menggunakan komputer dan melakukan pengaturan.

4. Pembatasan atas penggunaannya.

5. Melindungi anak dari terkoneksi dengan hal-hal yang dapat merugikan mereka.

6. Memaksimalkan penggunaan komputer bagi anak-anak.

Ketersediaan alat yang mampu mendeteksi secara cepat jejak-jejak kejahatan di ruang siber dan lain-lain. Dengan mencari solusi yang tepat terhadap keterbatasan-keterbatasan alat inilah yang masih menjadi pekerjaan rumah di Indonesia untuk menciptakan ruang siber yang aman dari kejahatan pornografi dan kejahatan lainnya berbasis siber terhadap anak-anak.

\section{Penutup}

Konsep Perlindungan anak dari korban kejahatan siber, yakni dengan mengkriminalisasikan perbuatan-perbuatan yang dianggap sangat urgen untuk dirumuskan menjadi tindak pidana dalam perundang-undangan siber di masa akan datang. Tawaran konsep perlindungan hukum terhadap sebagai korban kejahatan siber melalui pendekatan penal yaitu: Pertama, pemidanaan minimal khusus diancamkan padajenis tindak pidana yang dipandang menimbulkan disparitas pidana dan membahayakan atau sangat merugikan masyarakat yang diperberat oleh akibatnya. Kedua pidana ganti kerugian diberikan dengan tujuan untuk mengembalikan kepercayaan korban dalam menghadapi kehidupan. Kebijakan non penal yang diusulkan penulis yakni hukuman pembatasan akses internet yaitu negara mampu menyediakan ketersediaan alat pendeteksi secara cepat jejak-jejak kejahatan di ruang siber.

Dengan demikian dalam wujudnya membuat kebijakan terhadap perubahan-perubahan undangundang yang mampu menjangkau terhadap permasalahan kejahatan siber yang menjadikan anak sebagai korban serta pemerintah diharapkan mampu membuat sistem keamanan bagi anak dalam pemanfaatan siber yang dapat melindungi anak terhadap kejahatan siber yang dialaminya..

\section{Ucapan Terima Kasih}

Penelitian berasal dari sumber pendanaan Direktorat Riset dan Pengabdian Masyarakat, Direktorat Jenderal Penguatan Riset dan Pengembangan Kementerian Riset, Teknologi, dan Pendidikan Tinggi Republik Indonesia.

\section{DAFTAR PUSTAKA}

\section{A. Buku}

Aminanto, 2017, Politik Hukum Pidana 1, Kertamedia, Jember.

Andi Hamzah, 1986, Sistem Pidana dan Pemidanaan Indonesia dari Retribusi ke Reformasi, Cetakan Ke-1, Pradnya Paramita, Jakarta.

Arief, Barda Nawawi, et al., 1984, Pidana dan Pemidanaan, Badan Penyediaan Bahan Kuliah Fakultas Hukum UNDIP, Semarang. 1992, Teori-Teori dan Kebijakan

Pidana, Alumni, Bandung. , 2002, Kebijakan Hukum Pidana,

Citra Aditya Bakti, Bandung.
2003, Kapita Selekta Hukum

Pidana, Citra Aditya, Bandung.

Atmasasmita, Romli, 1996, Sistem Peradilan Pidana (Criminal Justice Sistem), Bina Cipta, Bandung.

Bentham, Jeremy, 2006, Teori PerundangUndangan Prinsip-Prinsip Legislasi, Hukum Perdatadan Hukum Pidana, Penerbit Nusamedia dan Penerbit Nuansa, Bandung.

Maulana, et al., 1967, Perundang-undangan Majapahit, Bhatara, Jakarta.

Sudarto, 1983, Hukum dan Hukum Pidana, Alumni, Bandung. 
Widiada Gunakarya SA., 1988. Sejarah dan Konsepsi Pemasyarakatan, CV. Amico, Bandung.

\section{B. Jurnal}

Ariani, Nevey Varida, "Implementasi UndangUndang Nomor 11 Tahun 2012 Tentang Sistem Peradilan Anak Untuk Melindungi Kepentingan Anak", Jurnal Media Hukum, Vol. 21, No. 1, 2014.

Candra, Puspita Adiyani, "Penggunaan Internet pada Anak-anak Sekolah Usia 6- 12 Tahun di Surabaya", Jurnal Commonline, Vol.1, No. 2, 2013.

Cassim, Fawzia, "Addressing the Challenge sposed by Cybercrime: A South African Perspective", Journal of International Commercial Law and Technology, Vol. 5, Issue 3, 2010.

Rochmawati, Weny, "Perilaku Pemanfaatan Internet (Internet Utilization of Behavior) (Studi Deskriptif tentang Pemanfaatan Internet untuk KepentinganHiburan dan Akademik di Kalangan Anak-anak di Kota Surabaya)", Jurnal Libri-Net, Vol. 1, No. 1, 2012.

S., Kandi Aryani, "Penerimaan Remaja terhadap Wacana Pornografi dalam Situs-Situs Seks di Media Online", Jurnal Penelitian Dinamika Sosial, Vol. 7, 2008.

Sulistio, Faizin, et al., "AlternatifModel Pemidanaan Tindak Pidana Pornografi Siber", Jurnal Arena Hukum, Vol. 9, No. 3, 2016.

Thantawi, et al., "Perlindungan Korban Tindak Pidana Siber Crime Dalam Sistem Hukum Pidana Indonesia”, Jurnal Ilmu Hukum, Vol. .2, No. 1, 2014.

Ulinnuha, Masyari, "Melindungi Anak dari Konten Negatif Internet: Studi Terhadap Perambaan Web Khusus Anak", Jurnal Sawwa, Vol. 8, No. 3, 2013.

\section{Makalah/Pidato}

Damanik, Ahmad Taufan, "The Efforts of ASEANACWC in Addressing the Trend of Sexual Crimes Against Children Online", Makalah,
Conference on Sexual Crime against Children Online: Law Enforcement and Regional Cooperation, Jakarta, 29 - 30 October 2012. Djanggih, Hardianto, et al, "Urgency Legal Aspects Of Growth Information Technology In Indonesia", Makalah, 12th ADRI 2017 International Multidiciplinary Conference, Bogor, 30 Maret-1 April 2017.

Reksodiputro, Merdjono, "Sistem Peradilan Indonesia (Melihat Kejahatan dan Penegakan Hukum Dalam Batas Toleransi)", Makalah, Pengukuhan Guru Besar Ilmu Hukum pada Fakultas Hukum Universitas Indonesia, Jakarta, 1993.

\section{Artikel Internet}

Kementerian Komunikasi dan Informatika Republik Indonesia, "Penetrasi dan Perilaku Pengguna Internet Indonesia", https://aptika.kominfo. go.id/index.php/berita/274-rilis-hasil-surveipenetrasi-dan-perilaku-pengguna-internetindonesia-tahun-2018, diakses Tanggal 20 Desember 2017.

Beritasatu, "Peraturan Kominfo tentang Pembatasan Akses Internet dinilai Langkahi Hukum", http://www.beritasatu.com/hukum/201797peraturan-kominfo-tentang-pembata-sanakses-internet-dinilai-langkahi-hukum.html, diakses tanggal 2 Nopember 2017.

\section{E. Peraturan Perundang-Undangan}

Undang-Undang Nomor 32 Tahun 2002 tentang Penyiaran (Lembaran Negara Republik Indonesia Tahun 2002 Nomor 139, Tambahan Lembaran Negara Republik Indonesia Nomor 4252).

Undang-Undang Nomor 44 Tahun 2008 tentang Pornografi (Lembaran Negara Republik Indonesia Tahun 2008 Nomor 181, Tambahan Lembaran Negara Republik Indonesia Nomor 4928).

Undang-Undang Nomor 33 Tahun 2009 tentang Perfilman (Lembaran Negara Republik Indonesia Tahun 2009 Nomor 141, Tambahan 
Lembaran Negara Republik Indonesia Nomor 5060).

Undang-Undang Republik Indonesia Nomor 35 Tahun 2014 Tentang Perubahan Atas Undang-Undang Nomor 23 Tahun 2002 tentang Perlindungan Anak (Lembaran Negara Republik Indonesia Tahun 2014 Nomor 297, Tambahan Lembaran Negara Republik Indonesia Nomor 5606).
Undang-Undang Nomor 19 Tahun 2016 tentang Perubahan Atas Undang-Undang Nomor 11 Tahun 2008 tentang Informasi dan Transaksi Elektronik (Lembaran Negara Republik Indonesia Tahun 2016 Nomor 251, Tambahan Lembaran Negara Republik Indonesia Nomor 5952). 